\title{
The Management of Non-Tax Revenue: an Evaluative Review
}

\author{
Nina Yusnita Yamin \\ University of Tadulako \\ ninayamin@untad.ac.id
}

\author{
Andi Mattulada Amir \\ University of Tadulako \\ mattulada@gmail.com
}

\author{
Magfirah Angraini \\ University of Tadulako \\ miss.angraini@gmail.com
}

\begin{abstract}
The study aims at describing and analyzing the management of non-tax revenues; the growth rate and effectiveness of non-tax revenues management; theobstacles faced in the management of non-tax revenues; and the offering alternative solution of nontax revenues management. The study applies qualitative method, using case study approach. Informants are the officials who are involved in the management of non-tax revenues atthe Land Office of Parigi Moutong Regency. The results show that nontax revenues management is not optimal inthephase of planning and budgeting, implementation and administration, supervision, reporting and accountability. The growth rate of non-tax revenues targets (2011-2015) increases, but the growth rate fluctuates annually. The non-tax revenue (2011-2015) isnot effective due to the inability of gaining the target. Obstacles found in the management of non-tax revenues are caused by the limited participation of budgeting preparation, lack of human resources both in terms of quality and quantity; weakness of system operational procedures and internal control system, lack of supervision in implementation, and financial report which is considered an administrative formality. Offering alternative solutions to overcome various obstacles, the management of non-tax revenue needsplanning and budgeting participation, employee recruitment, utilization of information technology, implementatingsupervision on system operational procedures, andsustainable evaluation.
\end{abstract}

Keywords: management, non-tax revenue, growth, effectiveness

\section{INTRODUCTION}

PNBP is one of the main sources of state revenues besides tax revenues regulated in Law No. 20 of 1997 and the tariff setting is regulated in government regulations governing the types and tariffs of non-tax revenues applicable to individual ministries / agencies [1], [2]. Non-Tax State Revenue as all central government revenue is not derived from tax revenue [3].

PNBP has nominally increased every year, but its contribution to state revenues is still relatively small and declining since 2011. In 2011 PNBP's contribution to state revenues amounted to $27.5 \%$, while in 2014 to $23.6 \%$ and predicted to be $15,27 \%$ by 2015 [4]. The data indicates a low growth in non-tax sector revenues indicating that non-tax revenues receive less government attention. This can be seen in the Audit Report of the State Audit Board of Indonesia from 2013 to 2015 stating that there are still some ministries/ institutions that are not orderly implementing the management of PNBP funds [5], [6], [7]. In fact, if PNBP is managed well, it can become one of the main pillars of domestic income because of its huge potential in Indonesia. Potential PNBP from mining, forestry, fishery and various resources and natural resources owned by Indonesia is still potential to be developed so as to increase state revenues.

The Ministry of Agrarian Affairs and Land Spatial / National Land Agency is one of the seven ministries / agencies that produce the largest contribution to other PNBP revenue. Based on the Financial Notes of RAPBN 2016, PNBP Ministry of Agrarian Affairs and Spatial / National Land Agency in the period 2010-2014 has an average increase of $14.1 \%$, mainly derived from land service revenues. Land Office of Parigi Moutong Regency as one of the Work Unit under the auspices of the Ministry of Agrarian Affairs and Spatial / National Land Agency also manages PNBP which is derived from the income of the Ministry of Defense services. However, the realization of PNBP remittance to the state treasury tended to increase only at the end of the year i.e. in the fourth quarter.Therefore, the realization of expenditures whose sources of funding come from PNBP become ineffective, ultimately impacts on the low performance of office finance. 


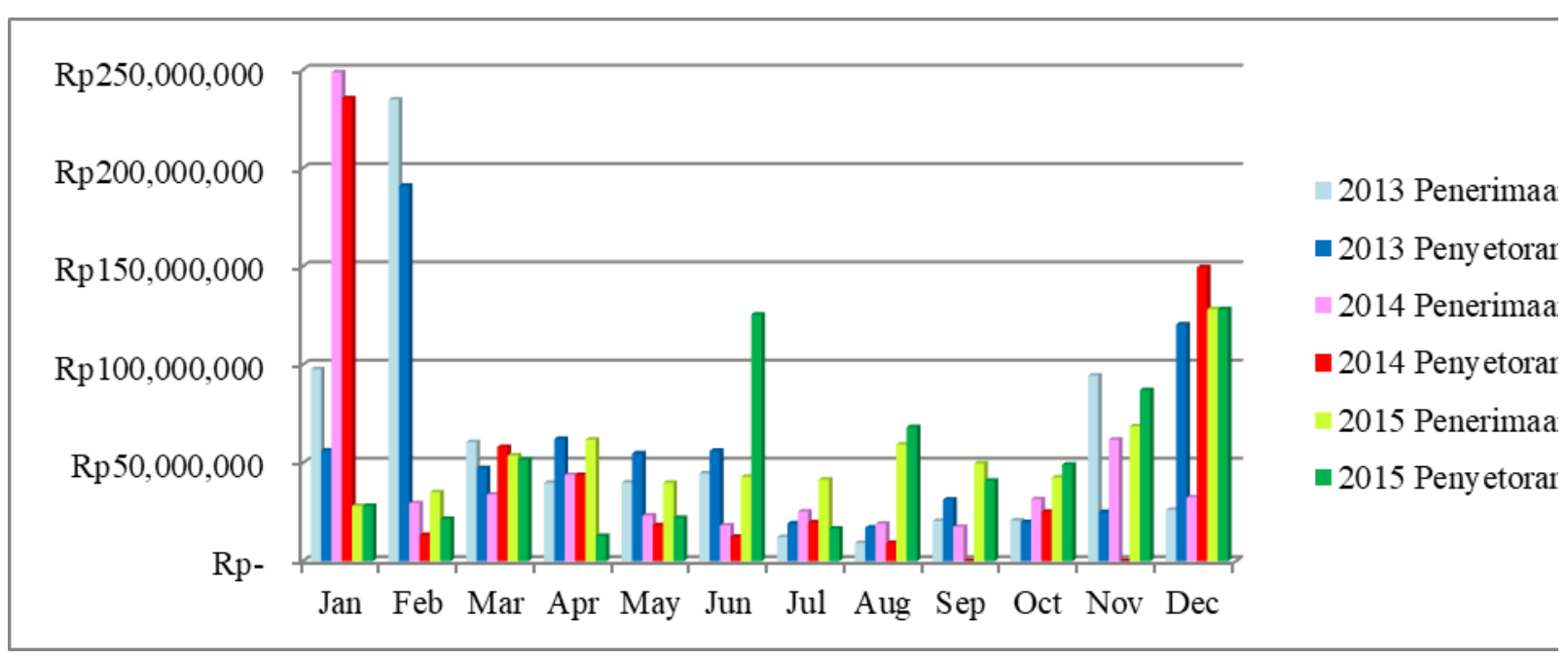

Source: Report of Cash Advance Working Unit of Land Office Parigi Moutong Regency (processed)

Figure 1. Realization of Receipt and Depositment of PNBP of Land Office Parigi Moutong Regency Year of 2013-2015

This is reinforced in the Inspectorate Performance Inspection Report of the National Land Agency of the Republic of Indonesia 2015 stating that the Parigi Moutong District Land Office Work Unit from 2013 to 2015 was always late in depositing PNBP funds to the state treasury. Realization of receipt and remittance of PNBP at the Land Office of Parigi Moutong Regency from 2013 to 2015 can be seen in Figure 1.

Seeing the realization of deposits lower than the realization of revenue at the beginning of the fiscal year, and the realization of deposits that far exceeds receipts at the end of the fiscal year, each year shows that the management of PNBP funds at the Land Office of Parigi Moutong Regency is still less orderly. The existence of the tendency of embezzlement due to weak system, the indication of the use of funds due to the existence of cash lapping is a way of embezzlingcash money by retiring the recording of cash receipts for a time not too long and may also be done for a very long time.Therefore, it needs to identify the problem causing disorders in the management of the PNBP funds.

\section{METHOD}

This research is a type of qualitative research using case study approach. The informants in this study are the employees involved in the management of PNBP which include: Head of Office, Head of Sub Division of Administration, Reception Treasurer, Expenditure Treasurer, and Payee Counter Officer; with key informant that is Head of Sub Division of Administration as direct superior of treasurer of acceptance.

Various data analysis techniques were conducted to support the results of this study, which comprised case study case analysis [8], growth analysis, and effectiveness analysis. As for testing the credibility of the data, researchers used triangulation model to check the accuracy of the results.

\section{RESULTS AND DISCUSSION}

The management of PNBP covers the activities of planning and budgeting phases, implementation and administration, monitoring and reporting and accountability.

\section{Limited participation of budget preparation}

The planning and budgeting phases of the Satker generally follow the law, in which the Satker has RKA-K/L contains the revenue targets to be obtained during one budget year and the budget ceilingto finance and implement the work plan. However, in the implementation of the planning and budgeting process of the Satker, there are several weaknesses. In relation to income targets, the facts on the ground indicate that the Satker is involved in the formulation of revenue targets, but the participation of the Satker context is only the completion of the target data and the realization of PNBP two years earlier and sent to the Provincial BPN Office, and the revenue target of PNBP is prepared by the Provincial BPN Office.

Based on the growth analysis, the PNBP target set by the Kanwil increases every year when the realization achieved is much lower than the expected target. This achievement shows that in the drafting of PNBP targets, the Regional Office does not refer to historical data or the realization of previous budget years.

Referring to Article 3 of Regulation of the Minister of Finance No. 152 of 2014 on the Guidelines for Preparation of Non-Tax State Revenue Plan of State Ministries/Institutions, the PNBP targets should be prepared realistically and optimally based on the estimated amount / volume on which PNBP is calculated from each PNBP type for each Budget Section, starting in the form of PNBP plan at the level of the Satker.

In relation to budget planning derived from PNBP, the facts in the field indicate that the Working Unit 
performs the planning and budgeting which is sourced from PNBP. However, budgeting is still not paying attention to the needs of Satkers.

Related to the need for participation in budgeting, Budgets can provide a basis for resource use and motivate employees. The big difference between the actual and planned results is the feedback that reveals that the system is not working [9].

\section{1) Weakness of systemsupervision and procedures (SPOPP) of Land Affairs}

Implementation phase and administration of PNBP in Satker found some weaknesses. Based on the observation, applicants who come to register to the counter is very minimal service. Most applications for land services are delivered through notaries, or through intermediaries. This situation illustrates the service system through the counter is still not fully under the SPOPP Land which shows weak internal control system. Registration that is not through the counter can lead to irregularities in terms of payment or service charges which show the weakness of internal control system.

Data of Cash Receiving Currency Report (LKKUP) for the last 5 (five) years shows almost every month there is a balance of PNBP revenue that has not been paid to the state treasury. Poorly managed deposit mechanisms from the previous year also show internal controls and control over low system implementation.

1. Growth Level and the Effectiveness of PNBP Management

The growth trend of PNBP targets in the Land Office Unit of Parigi Moutong Regency during the period of 2011-2015 fluctuated, but increased every year.

The planning process of the PNBP target of the Satker showed not through the evaluation process, not yet carefully planned, either by the Provincial BPN as the The right man in the right place

The human resources are very minimal, both in terms of quantity and quality. The Acceptance Treasurer is held by the Land Rights and Land Registration Analyst with an undergraduate background in Law, who has no knowledge of finance, and has no experience at all in finance or treasury.

The Acceptance Treasurer has also not been certified and has never attended any financial education and training, the Expenditure Treasurer and other financial managers.

\section{The financial statements are still "administrative formalities"}

Based on the facts in the field, the Satker reports and conducts reconciliation every month because it is only a duty that must be implemented by the Satker, but the report is still 'administrative formality'. The contents of the report are not used as information for Satkers and Regional Offices as Echelon II Unit in charge of guidance/monitoring and evaluation. Based on the results of interviews with Head of Sub Division, it is known that there is no special counseling / monitoring and evaluation on PNBP management

target party or the Satker itself. It also shows that the Satker does not use the data generated from the financial statements annually for evaluation in planning and budgeting.

\section{Alternative Solution of PNBP Management Mechanism}

Based on analyzes that researchers have pointed out earlier, and then some alternative solutions can be given as follows:

1) The researcher proposes that the Satker proposes to the Provincial BPN Office to be included in the budget preparation process. Thus, the Satker may prepare its own revenue and expenditure budget by firstly testing the targets, realization, and constraints and obstacles by involving all operational management.

2) Related to the implementation, the researcher proposes the need for new innovations in the procedures of land services, by using information technology, which creates an online application with an integrated system.

3) Related to the constraints, the supervisory phase shows the lack of supervision. The role of the auditor in the planning, implementation, and accountability phases needs to be designed in a straightforward and systematic way so that the value added generated by the auditor can provide effective results to refine the results of each budget cycle.

\section{CONCLUSION}

The management of PNBP in the Land Office Unit of Parigi Moutong Regency is still not optimal in the planning and budgeting phase, implementation and administration, supervision, and reporting and accountability.

The growth rate of PNBP targets (2011-2015) increases, but the realization growth of non-tax revenues fluctuates annually. While the effectiveness of PNBP management (2011-2015) is still not effective, the realization of acceptance did not reach the target.

The obstacles faced in the management of PNBP in the Land Office Work Unit of Parigi Moutong Regency is the lack of budgetary participation, the weakness of the supervision of the Standard Operating Procedure for Land Management and Regulation, the weakness of the internal control system, the minimum supervision and financial report is fulfilled based on administrative formality.

The needs are intended for participation in planning and budget formulation, utilization of information technology to improve service, improvement of supervision on SPOPP land implementation, and continuous evaluation 


\section{REFERENCES}

[1] Badan Pertanahan Nasional Republik Indonesia. 2014. Laporan Hasil Pemeriksaan Kinerja Inspektorat Utama Badan Pertanahan Nasional Republik Indonesia Nomor: 32/023-700.33/RST.14/VII/2014 tanggal 17 Juli 2014.

[2] Badan Pertanahan Nasional Republik Indonesia. 2015. Laporan Hasil Pemeriksaan Kinerja Inspektorat Utama Badan Pertanahan Nasional Republik Indonesia Nomor: 98/023-900.33/RST/XII/2015 tanggal 28 Desember 2015.

[3] Halim, Abdul. 2014. Manajemen Keuangan Sektor Publik Problematika Penerimaan dan Pengeluaran Pemerintah. Jakarta: Penerbit Salemba Empat.

[4] Kementerian Keuangan Republik Indonesia. Nota Keuangan beserta Rancangan Anggaran Pendapatan dan Belanja Negara Tahun Anggaran 2016. Melalui http://www.anggaran.depkeu.go.id/Content/Publik asi/NK\%20APBN/NK\%20RAPBN\%202016.pdf. Diakses 18 Juli 2016.

[5] Badan Pemeriksa Keuangan Republik Indonesia. 2014. Laporan Hasil Pemeriksaan BPK RI Tahun 2013 atas Kepatuhan terhadap Peraturan Perundang-undangan Nomor 69c/LHP/XV/05/2014 tanggal 28 Mei 2014.
Melalui

http://www.bpk.go.id/assets/files/lkpp/2013/lkpp 2013 1402973864.pdf. Diakses 18 Juli 2016.

[6] Badan Pemeriksa Keuangan Republik Indonesia. 2015. Laporan Hasil Pemeriksaan BPK RI Tahun 2014 atas Kepatuhan terhadap Peraturan Perundang-undangan Nomor 74c/LHP/XV/05/2015 tanggal 25 Mei 2015. Melalui

http://www.bpk.go.id/assets/files/lkpp/2014/lkpp 2014 1433387141.pdf. Diakses 23 Juni 2016.

[7] Badan Pemeriksa Keuangan Republik Indonesia. 2016. Laporan Hasil Pemeriksaan BPK RI Tahun 2015 atas Kepatuhan terhadap Peraturan Perundang-undangan Nomor 56c/LHP/XV/05/2016 tanggal 26 Mei 2016. Melalui http://www.bpk.go.id/assets/files/lkpp/2015/lkpp 2015 1465543248.pdf. Diakses 28 Juni 2016

[8] Creswell, John W. 2010. Research Design Pendekatan Kualitatif, Kuantitatif, dan Mixed. Terjemahan Achmad Fawaid. Yogyakarta: Pustaka Pelajar.

[9] Hansen, Don R. dan Mowen, Maryanne M. 1999. Akuntansi Manajemen. Alih Bahasa Hermawan, Ancella A. Jakarta: Erlangga 